\title{
The disappearance of dedicated biotechnology firms in Canada
}

\author{
Ayoub Moustakbal \\ Department of Management and Technology, \\ Canada Research Chair on the Management of Technology, \\ University of Quebec at Montreal, \\ P.O. Box 8888, Station Centre-Ville, \\ Montreal, QC, H3C3P8, Canada \\ Fax: 1-514-987-3343 \\ E-mail: moustakbal.ayoub@uqam.ca
}

\begin{abstract}
The present paper has the objective of understanding the disappearance of biotechnology firms. To accomplish this objective, a sample was built from 552 firms operating in Canada between 1996 and 2010. The results reveal that disappearance is not only due to filing for bankruptcy, but also due to change in firms' names, as well as mergers and acquisitions (M\&A). Statistical tests further show that the survival of dedicated biotechnology firms (DBFs) depends mainly on two factors: having a qualified management team, and receiving the support of the venture capital firms. In addition, the results demonstrate that firms which mainly operate in the human health sector and have already received support from VC opt for M\&A to exit the industry. This study has some practical lessons for different stakeholders concerning the survival and the exit of new enterprise biotechnology firms.
\end{abstract}

Keywords: dedicated biotechnology firms; DBFs; venture capital; bankruptcy; mergers and acquisitions; M\&A; management team; strategic management; Canada; biotechnology; disappearance.

Reference to this paper should be made as follows: Moustakbal, A. (2014) 'The disappearance of dedicated biotechnology firms in Canada', Int. J. Biotechnology, Vol. 13, Nos. 1/2/3, pp.66-89.

Biographical notes: Ayoub Moustakbal is $\mathrm{PhD}$ candidate and Lecturer at the Department of Management and Technology, Université du Québec à Montréal. In addition, he is an Assistant Researcher in Canada Research Chair on the Management of Technology.

\section{Introduction}

In this study, we adhere to the definition given by the OECD which is the most widely used in the scientific literature. OECD (2005) defines biotechnology as: "The application of science and technology to living organisms, as well as parts, products and models thereof, to alter living or non-living materials for the production of knowledge, goods and services". 
Further, we focus on dedicated biotechnology firms (DBFs) defined by $\operatorname{OECD}(2005,2009)$ as: “A biotechnology firm whose predominant activity involves the application of biotechnology techniques to produce goods or services and/or to perform biotechnology R\&D”.

Biotechnology is considered a strategic economic sector to form a technological platform to promote socioeconomic prosperity in Canada (Conference Board of Canada, 2005). The efforts already made by Canada's federal government to develop this sector have placed this country among the world leaders. The last statistics published by the OECD (2009) show that Canada surpasses the majority of its country members in terms of number of DBFs created proportionate to its population. In fact, between 1996 and 2010, the number of DBFs has increased over 100\%. DBFs grew in number from 282 in 1997 to 532 in 2005 and then increased again to 572 in 2010, according to the latest statistics published by Biotech Canada in 2011. The growth of DBFs was matched to revenue increases that have moved from 876 USD million to more than 4.2 USD billion, which represents a $379 \%$ increase. In terms of R\&D investments, there is also important growth because the amount invested by DBFs has evolved from 532 USD million to more than 1.54 USD billion (Statistics Canada, 2007).

However, there are some voices warning about the disappearance of young biotechnology firms as well as economic results well below expectations (Pisano, 2006; Niosi, 2011). Indeed, when consulting the Canadian guides on the biotechnology industry, one important fact which emerges is that the list of firm names changes from year to year. Arrival of new firms is related with disappearance of certain former players. This trend which has been confirmed by our results reveals that almost half of the firms have been disappeared. In terms of literature and scientific studies, we have noted that, after more than three decades, few authors had tried to understand different steps following the birth of DBFs. In other words, DBFs' disappearance or survival phenomenon is less studied or has been less under the spotlight. To our knowledge, most of the past research has been focused on the factors that determine creation and growth.

We, therefore, decided to fill the gap in the relevant literature by focusing on the following objectives:

1 to evaluate the extent of the phenomenon and to identify the different forms in which young biotechnology firms disappear

2 to identify the factors which explain the disappearance of those firms (e.g., venture capital support, intellectual property protection strategies and the presence of qualified management teams).

\section{Literature review}

To explore the evolution of the life cycle of the DBFs, we use different theoretical approaches related with the resource-based view (RBV). In her pioneering work about the theory of the firm, Penrose (1959) explains that differences in growth among organisations are due to their differences in internal resources, and specifically about differences in managerial competences. Based on Penrose's insights, different authors have progressed further. For example, the approach of the dynamic capacities which stresses that an organisation's prosperity is based mainly on the capacity of executives to 
put in place a strategic management able to reconfigure the internal resources and the creation of organisational capacities (Teece, 2009). In the same vein, Eisenhardt and Martin (2000) define these dynamic capabilities as: “The firm's processes that use resources - specifically the processes to integrate, reconfigure, gain and release resources - to match and even create market change. Dynamic capabilities thus are the organizational and strategic routines by which firms achieve new resource configurations as markets emerge, collide, split, evolve, and die".

\subsection{Disappearance of DBFs}

Further to their study that investigates the determinants of failure for new Canadian firms, Baldwin et al. (2000) conclude that disappearance is a destiny more likely than survival of young companies dedicated to products or services. For his part, Mata (1994) has announced that in a turbulent economy, many small new firms are created, but a great proportion of them die in their first years of existence. To explain this infantile death phenomenon, Hannan and Freeman (1977) note that leaders of new enterprises must manage two types of obstacles: 'liability of newness' and 'liability of smallness'. New firms face a lack of appropriate resources to put their strategies in place, and a lack of adequate skills to take proper decisions (Jovanovic, 1982).

In the UK, for example, Anyadike-Danes et al. (2009) state that among the 221,731 new firms created in 1998 , only 83,165 have survived up to 2008 , which means a survival rate not exceeding $37.5 \%$. In the same vein, Song et al. (2008) indicate that only $21.9 \%$ of companies surveyed reach their fifth birthday. According to a longitudinal study based on a sample of 11,259 start-ups operating in the USA between 1991 and 2000, Song et al. (2008) determine eight homogeneous factors explaining the demise or survival of these companies such as: age of companies, size of the founding team of the company strategies of intellectual property protection, access to financing, market size, experience of leaders in industry and in marketing.

However, Cefis and Marsili (2011) reveal that high-tech companies are more likely to exit industry through mergers and acquisitions (M\&A) transactions than through bankruptcies. In the case of biotechnology firms, Carroll and Hannan (1995) claim that bankruptcy is a rare event. These authors mention that in the USA this type of firms disappear mostly by M\&A as well as changes in name. This brings us to link with a recent report published by Ernst and Young (2012) which announces that the volume of M\&A had augmented in an impressive way, in the case of young biotechnology firms in particular. By the same token, Carayannopoulos and Auster (2010) argue that biotechnology is different from other high technology sectors because it has more complex and valuable knowledge. These authors explain that this incites the different stakeholders (e.g., big pharma and young biotechnology firms) to adopt M\&A strategies. For their part, Danzon et al. (2006) show that small firms, having financial problems and few commercial products, have a higher chance of being involved in M\&A. Nevertheless, Haeussler (2007) did not find a significant statistical relationship to affirm that financial trouble was a decisive factor for firms engaging in M\&A. This type of disappearance has more to do with the strategic visions of the executives than with a reactive action derived from a lack of financial resources. Haeussler (2007) reveals that Biotechnology firms having inter-firm collaborations are more likely to engage in M\&A.

Inspired by the literature cited above, we want to test the two hypotheses listed below; at the same time, we consider it relevant to further explore the literature that 
studies the impact of the managerial team on the survival or death of Canadian biotechnology firms.

$\mathrm{H}_{1}$ DBFs have a longer life expectancy than companies specialising in products or services.

$\mathrm{H}_{2}$ Disappearance of DBFs is not necessarily a sign of failure and bankruptcy. It is also related to merger and acquisition transactions.

\subsection{Qualified management team}

Several studies indicate that the presence of qualified and diversified management team is a key factor for growth and success of high-tech companies (Niosi, 2003; Rothaermel and Deeds, 2006; Lester et al., 2006; Rhyne, 2009). Zucker et al. (1998), for example, demonstrate that significant statistical relationships exist between the performance of young US biotechnology firms and the presence of a star scientist. More recently, Niosi and Queenton (2010) obtain similar results for Canadian companies. However, Rhyne (2009) shows that the importance of competences related to manufacturing operations, commercialisation, and public relations become more important as the product moves on in its life cycle. Rhyne (2009) further states that business management competences and financial planning are very important in the different stages of the development of a new product. The competences related with the management of innovation and new technologies are among the decisive factors for the success or failure of a firm (Baldwin and Gellatly, 2006).

In biotechnology, the lack of know-how and dynamic skills for business management could imply the impossibility of obtaining venture capital (Canada Industry, 2002). This last point is related to the work of Patzelt et al. (2007), which argues that executives with professional experiences in the venture capital sector are in a better position to obtain funding from public markets. Patzelt et al. (2007) also mentions that executives with international experience can profit from their personal networks to establish partnerships with venture capital firms and/or other funds donors (e.g., big pharma, research funds, angel investors). Therefore, even in uncertain environments, the prestige and quality of the executive team send a positive signal to secure different stakeholders, especially the fund donors (Lester et al., 2006).

Rothaermel and Deeds (2006) explain that executives should have a certain level of ability and appropriate experience in order to manage the risks of asymmetric information and opportunism that originate from certain business partners. In the same fashion, Niosi (2003) warns that the success of strategic alliances adopted by young biotechnology firms depends on the capacity of executives to choose the right moment to enter them (neither early nor late). These insights lead to the formulation of the following hypothesis:

$\mathrm{H}_{3}$ DBFs with a qualified and experienced management team have a longer life expectancy.

\subsection{Venture capital support}

Biotechnology firms are characterised by intensive R\&D activities, long product development life cycles, high technological and commercialisation uncertainty, and 
foremost, large financial needs (DiMasi et al., 2003). Thus, venture capital intervention becomes inevitable insofar as these financial organisations offer the most adequate funding and support for young high technology firms (Gompers and Lerner, 2001). In the same way, Kenny (1986) and Powell et al. (2002) note that the US biotechnology firms benefit from a geographical concentration of two critical factors for the development of the biotechnology sector: ideas and money.

Venture capital firms do not limit themselves to being simple fund donors; they also offer guidance to young innovative firms and they connect them with other business partners (Gompers and Lerner, 2001). Executives of these financial organisations play a crucial role in the development and professionalisation of managerial competences of their clients. Regarding this last point, Baum and Silverman (2004) posit that in Canada, venture capital firms choose and build winners. They have a scouting and coaching role that is behind the success of biotechnology firms.

In order to properly assimilate the mission and the added value of such financial institutions, it is critical to understand the life cycle of venture capital investments (Gompers and Lerner, 2001). Transactions undertaken by managers of venture capital institutions can be summarised in three steps (Black and Gilson, 1999; Hochberg et al., 2007; Hall and Lerner, 2010). Initially, these managers will raise capital from various institutional investors. Thereafter, they will begin the investment stage during which they select projects, grant funds and provide the appropriate guidance. Finally, there is the exit stage where these managers leave projects through initial public offering (IPO) strategy (Hochberg et al., 2007) or through M\&A to sell their shares to other investors (Cumming, 2008). This encourages us to test the following assumptions:

$\mathrm{H}_{4}$ DBFs that receive the support of venture capital firms have a longer life expectancy.

$\mathrm{H}_{5}$ Disappearance of DBFs that have support from venture capital firms is most evident in the merger and acquisition transactions.

\subsection{Intellectual property protection}

In high technology industries (e.g., biotechnology, software and aerospace), strategic patenting is a crucial factor in the success of young firms. Patents are an important criterion to measure the quality of the knowledge production process within a firm (Zucker et al., 1998).

In relation with previous hypotheses, Wilbon (2002) indicates that the high technology organisations that survive are the ones that have an experienced management team able to foresee an efficient intellectual property strategy (patents and licenses). Such a strategic choice allows young firms to acquire a long-term competitive advantage and to erect barriers for new entrants. Patents are considered as an instrument that enables the start-ups to protect the commercial advantages of their inventions until their expiration date. Also, firms benefit from spillovers resultant of this kind of strategic choice such as viability and visibility. For example, the US biotechnology firms which carried out R\&D activities had more chances to obtain national and international patents, and they were more likely to obtain revenues streaming from research contracts and licenses (Hall and Bagchi-Sen, 2001). Furthermore, patents allow start-ups to collect a return on R\&D investments, and to get a kind of certification which can be used to capture the attention of different stakeholders (Zucker et al., 2002; Niosi, 2003). 
It is also noteworthy to mention that firms dedicated to human health have the first position in terms of patents (OECD, 2009). In Canada, biotechnology firms dedicated to human health represent the lion's share regarding almost all indicators such as number of firms, employment, revenues and R\&D investment (Statistics Canada, 2007). For instance, in 2005 the investment in $R \& D$ made by biotechnology firms dedicated to human health was estimated to be over 1.4 billion USD representing $87 \%$ of the total (Statistics Canada, 2007). This type of DBFs has greater chances to develop and grow to the extent that they have more chances to access the services of venture capital firms and to establish partnerships with strategic stakeholders (Niosi, 2003; Van Moorsel et al., 2007). These insights lead to the formulation of the sixth and the seventh hypotheses:

$\mathrm{H}_{6}$ DBFs having at least one registered patent in the USPTO have a longer life expectancy.

$\mathrm{H}_{7}$ DBFs specialised in human health have a longer life expectancy.

\section{Sample and methodology}

This paper is part of large longitudinal study on the disappearance of the Canadian DBFs. The database used in this study has been built over a three-year time frame; and it includes more than 1,000 firms operating within the time period between 1996 and 2010. We used two related sources of information to build the database: electronic databases (consulted online), as well as documents and guides in paper format. To gather information concerning quantity and quality of patents held by the sampled firms, we consulted the United States Patent and Trademark Office (USPTO). For firms with access to venture capital financing, we examined the Canadian database 'Thomson Venture Capital Reporter'. This last database contains different and updated information such as: sums invested, financing stage, investor profile, objective of the financing, etc. In addition to collecting other relevant information regarding age, employment, sector of activity, management team, business partners, products in development and in market, exports, investment in R\&D, and revenues, we used several databases specialising in biotechnology (e.g., Biotech Canada, Statistics Canada, Industry Canada, and Biotech Gate). Finally, various editions (1996, 2000, 2005 and 2008) of 'the Canadian Biotechnology Guide' in paper format have been regularly consulted with the objective of validating some of the collected data.

To verify our research hypotheses, we codified the independent and dependent variables according to the following binary model (see Table 1). However, we want to specify that for companies that disappeared, the 'life expectancy' (dependant variable) is the difference between the year of creation and the year of bankruptcy or the year of M\&A. For surviving firms, the life expectancy is the difference between the year of creation and the year 2010. Regarding the independent variable: 'team management', we refer to the presence of a star researcher, i.e., a researcher having over thirty scientific publications and patents, of a marketing manager, and of an experienced CEO. So, a director with a high level of education and more than 25 years of experience in the biopharmaceutical industry and/or venture capital industry is considered in our research as a suitable respondent. 
Table 1 Summary of dependent and independent variables

\begin{tabular}{|c|c|}
\hline Dependent variables & Independent variables \\
\hline $\begin{array}{l}\text { Survival } \\
(\mathrm{Yes}=1 / \mathrm{No}=2)\end{array}$ & $\begin{array}{l}\text { Venture capital support } \\
(\text { Yes }=1 / \mathrm{No}=2)\end{array}$ \\
\hline \multirow{2}{*}{$\begin{array}{l}\text { Life expectancy } \\
\text { Mergers and acquisitions } \\
(\mathrm{Yes}=1 / \mathrm{No}=2)\end{array}$} & $\begin{array}{l}\text { Patent } \\
(\mathrm{Yes}=1 / \mathrm{No}=2)\end{array}$ \\
\hline & Qualified management team (composed of an experienced CEO, \\
\hline \multirow{6}{*}{$\begin{array}{l}\text { Bankruptcy } \\
(\mathrm{Yes}=1 / \mathrm{No}=2)\end{array}$} & $\begin{array}{l}\text { a } R \& D \text { director, and a marketing director }) \\
(\mathrm{Yes}=1 / \mathrm{No}=2)\end{array}$ \\
\hline & $\begin{array}{l}\text { Firms dedicated to human health } \\
(\text { Yes }=1 / \mathrm{No}=2)\end{array}$ \\
\hline & $\begin{array}{l}\text { Firms dedicated to agriculture } \\
(\mathrm{Yes}=1 / \mathrm{No}=2)\end{array}$ \\
\hline & $\begin{array}{l}\text { Firms dedicated to environment } \\
(\text { Yes }=1 / \mathrm{No}=2)\end{array}$ \\
\hline & $\begin{array}{l}\text { Firms dedicated to medical technologies } \\
(\mathrm{Yes}=1 / \mathrm{No}=2)\end{array}$ \\
\hline & $\begin{array}{l}\text { Firms dedicated to other sub category } \\
(\text { Yes }=1 / \mathrm{No}=2)\end{array}$ \\
\hline
\end{tabular}

To analyse the collected data, we carried out different statistical tests using the latest version of SPSS such as: chi-square, Pearson correlation coefficients, multicollinearity tables, and logistic regressions.

It must be stressed that we have chosen those independent variables which have been identified as indispensable variables for the growth of biotechnology firms in several past studies (Powell et al., 2002; Niosi, 2003, 2011; Baum and Silverman, 2004; Niosi and Queenton, 2010). In the same sense, Canadian Life Science (2011) tells us that "to build successful biotechnology companies, we need science, commercialization, capital and experienced people. If we don't have the right ingredients, we will not be able to bake the cake".

\section{Results}

\subsection{Sample main characteristics}

It is pertinent to highlight certain characteristics of the sampled firms in Tables 2 and 3. First of all, we notice that Canadian Biotechnology is dominated by small DBFs-having less than 50 employees - which represent about $73 \%$ of our sample. Human health sector holds the gold medal in terms of having the highest number of the companies. In fact, $57 \%$ of DBFs identified are dedicated to human health sub-sectors (e.g., Therapeutics, Bioinformatics, Analytical, Genomics and Proteomics). Regarding the geographic dispersion, the province of Quebec is in first place as it is home to about $33 \%$ of the sampled firms, followed by Ontario with $29 \%$, and British Columbia with $17 \%$. The rest of the firms, i.e., $21 \%$ are spread across other provinces of Canada. 
Table 2 Main characteristics of Canadian DBFs (1996-2010)

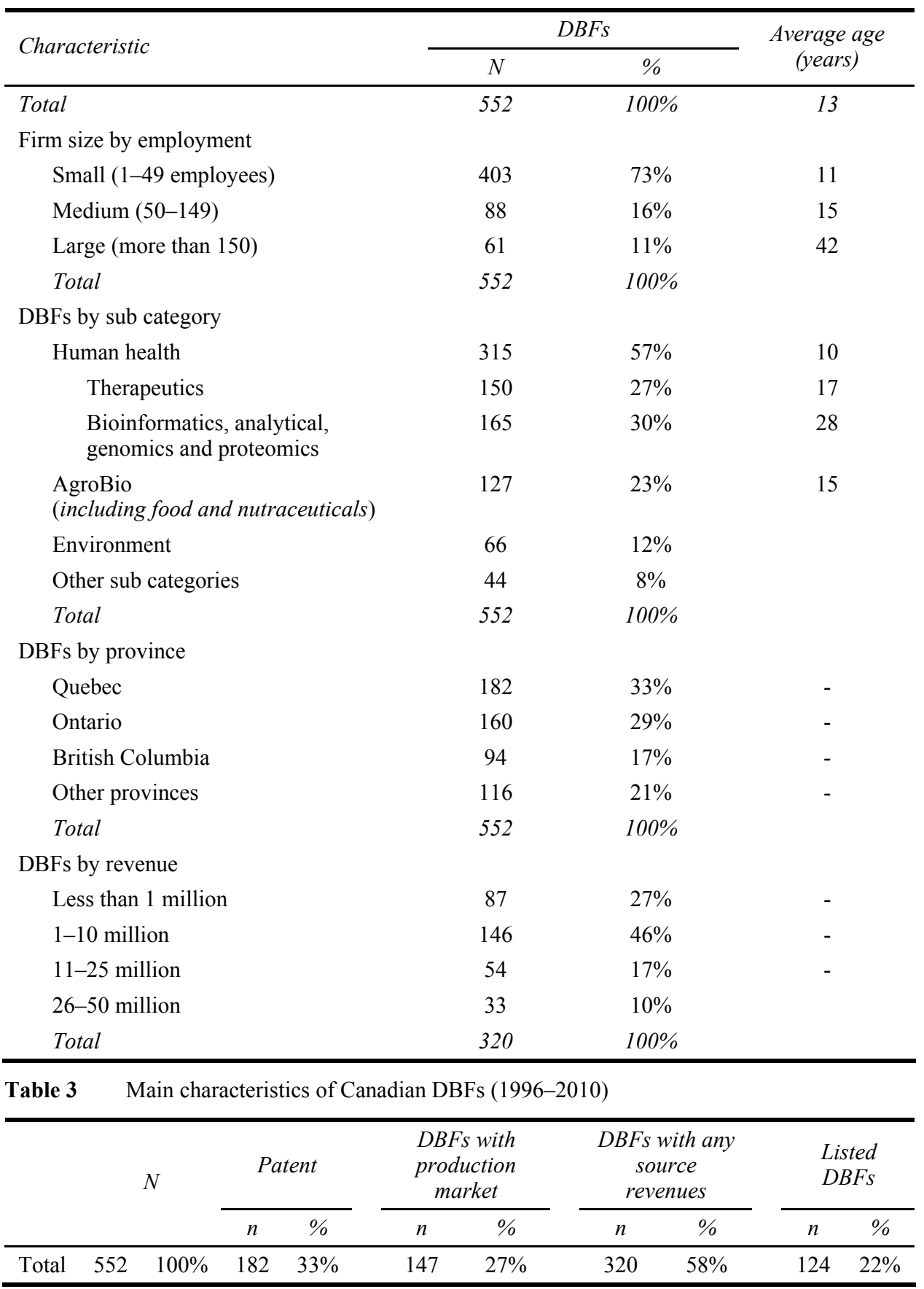


Our longitudinal study reveals that the average age of our sample is 13 years. Nevertheless, we have to distinguish between large firms that survive longer (42 years) and small businesses whose average age is not exceeding 11 years. Likewise, the average age of DBFs varies by biotechnology sector they are in. With an average age of ten years, firms dedicated to human health seem to survive less than companies dedicated to the environment having an average age of 28 years.

In terms of revenues from all sources, $58 \%$ of the surveyed DBFs have earned revenues. The human health sector holds the largest share of biotechnology revenues. Moreover, we must recognise that the vast majority of these identified DBFS have not won enough income. Between 1996 and 2010, almost three-quarters of DBFs (73\%) have an income that does not exceed $\$ 10$ million. In addition, $27 \%$ of DBFs have earned less than $\$ 1$ million.

Table 3 shows that only $33 \%$ of DBFs have at least one patent registered in the USPTO; while the portion of DBFs having at least one product on the market does not exceed $27 \%$. Finally, based on Table 3 we can emphasise that $22 \%$ of companies surveyed have used public savings (DBFs listed in stock exchange).

Our longitudinal study of Canadian DBFs reveals that several names change from year to year. More precisely, we discovered that more than half $(54 \%)$ of the identified names in our sample disappeared between 1996 and 2010 (see Figure 1). According to our study, the firms' disappearances occurred for the following reasons:

1 transactions of acquisitions (24\%) and mergers (4\%)

2 bankruptcies $(16 \%)$

3 changes in name $(10 \%)$.

Figure 1 The different ways of DBF's disappearances in Canada (see online version for colours)

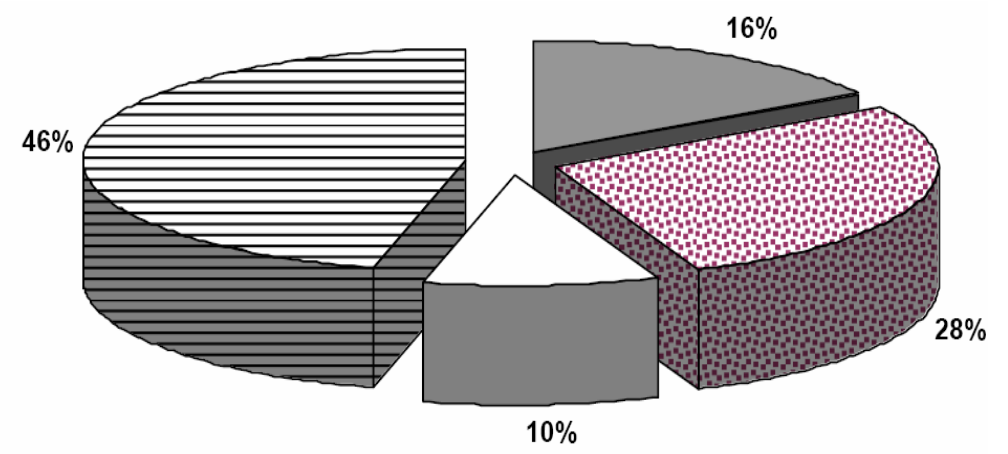

口Bankruptcies

ㅁ M\&A

$\square$ Changes in name

ロSurvivors

In this paper, we are interested more by disappearances linked to bankruptcy and M\&A on which we want to shed more light through different hypotheses laid down in the literature section. In other words, our study aims at consists in understanding and analysing the disappearance of $43 \%$ of the sampled firms located in different Canadian provinces operating in the period 1996-2010. 
Regarding our first hypothesis, we see that contrary to firms dedicated to manufacturing or services, DBFs have a long life expectancy. In the manufacturing sector, Baldwin and Gellatly (2003) indicate that almost half of new firms exit industry before their third birthday and they add that only one in five new firms gets to its second decade of operation. However, our study reveals that $57 \%$ of Canadian DBFs have survived more than ten years. We want to add that our sample of 552 DBFs shows an average age of 13.56 years and a median age of 12 years. Given these first results, we can say that our research has confirmed our first hypothesis which assumes that Canadian DBFs have a longer life expectancy than firms specialising in products or services.

Beyond factors that we will see later, the long life expectancy that characterises DBFs can be justified also by generous and favourable Canadian institutional environment (e.g., national and regional innovation systems) encouraging the creation and development of young firms dedicated to biotechnology through different fiscal incentives, subventions and a favourable legal framework (Cooke et al., 2004). DBFs can also benefit from being established in large metropolises where they exploit different cognitive and economic externalities such as: availability of scientific facilities (e.g., universities, hospitals and research laboratories), mobility of qualified human resource and the presence business partners networks (Audretsch, 2002; Niosi and Banik, 2005). Finally we should point out that DBFs can often survive more than firms specialising in products or services because their managers can count on appropriate financial systems (e.g., venture capital firms and stock markets) responding to their firms' expectations and needs (Kenney, 1986, 2011).

By the same token, our results agree with those obtained by Carroll and Hannan (1995) for the US biotechnology firms. These results confirm our second hypothesis too, in the sense that the disappearance of biotechnology firms is not due, solely, to bankruptcy; but mainly to M\&A (Haeussler, 2007) and changes in name (Carroll and Hannan, 1995). Thus, our sample of 552 DBFs reveals that almost two thirds of disappearances are due to M\&A, and that a quarter of the firms have been involved in M\&A. To explain this situation, McKelvey (2008) indicates that the fragmentation of Canadian biotechnology and technological competition between the new and old companies is an important factor to explain the upward trend of merger and acquisition transactions.

$\mathrm{H}_{3}$ DBFs with a qualified and experienced management team have a longer life expectancy.

Our statistical tests show a significant relationship between the presence of qualified management team and survival probability of young DBFs. In more concrete terms, there is a significant positive correlation $(r=.364, p=.000)$ indicating that Canadian DBFs steered by qualified leaders (Man_Team) have a greater chance of long life expectancy. Our sample reveals that in the period 1996-2010, 78\% of surviving firms were under the direction of a qualified management team (Man_Team) composed of at least an experienced CEO (25 years or plus), a R\&D director, and a marketing director. 
As we have pointed out in literature review, the presence of a qualified management team offers to those firms the expertise needed in terms of R\&D activities management, financial planning, and commercialisation policy. In addition, the presence of a qualified management team (Man_Team) provides those firms with some sort of socioeconomic legitimacy. These leaders gain advantages from their personal networks (strong and/or weak ties in the sense of Granovetter, 1973) in order to obtain new ideas (e.g., Universities and research laboratories), to access new markets and to tap into new financing sources. Regarding the last point, our statistical tests show a significant relationship and a positive correlation (see Table 4) between venture capital support (VC-sup) and the presence of a management team. This fact might be interpreted under two complementary perspectives. On the one hand, DBFs having a qualified management team are better suited to obtain venture capital support. On the other hand, the screening and follow-up processes put in place by venture capital firms make it more likely that those DBFs will end up handled by a qualified management team.

$\mathrm{H}_{4}$ DBFs that receive the support of venture capital firms have a longer life expectancy.

Following our review of the 'Thomson Venture Capital Reporter database', we found that between 1996 and 2010, more than half of the studied firms (51.27\%) had established a business relationship with venture capital firms. Firms dedicated to human health represent more than two thirds (68\%) of the total number of firms that received support from venture capital firms.

However, our statistical results are not clear enough to pronounce regarding the fourth hypothesis because our chi-square test does not indicate statistical significant relationships $(r=.138, p=-.063)$ (Table 4$)$. So in our sample, venture capital support (VC_sup) does not influence the life expectancy of the DBFs. It is possible that the executives of this kind of company rely on other sources of funding such as public grants, private research funds (e.g., Bill and Melinda Gates Foundation), angel investors and/or big pharmaceutical companies.

$\mathrm{H}_{6} \quad$ DBFs having at least one registered patent in the USPTO have a longer life expectancy.

$\mathrm{H}_{7}$ Biotechnology firms dedicated to human health have a longer life expectancy.

Concerning intellectual property, our research reveals that between 1996 and 2010 only one firm out of three had at least one quality patent registered in the USPTO. Also, our results show that only $37 \%$ of the firms that survived had at least one patent. It seems that intellectual property protection is not part of a strategic orientation followed by leaders of Canadian biotechnology firms. Otherwise our statistic tests show non-significant correlation between the presence of patents and survival DBFS $(r=-.022, p=.598)$. So our sixth hypothesis can neither be accepted nor rejected.

Regarding our last hypothesis, all the tests conducted through SPSS indicate a negative correlation (see Tables 4 and 5) between survival and specialisation in human health (H_Health) $(r=-.203, p=.000)$. In other words, the Canadian biotechnology firms dedicated to human health (H_Health) are more likely to disappear than firms specialised in other subcategories. Therefore, our last hypothesis is rejected. Our logistic regression tests confirm and complement the results mentioned above (see Table 3). 
Table 4 Survivor DBFs' correlation

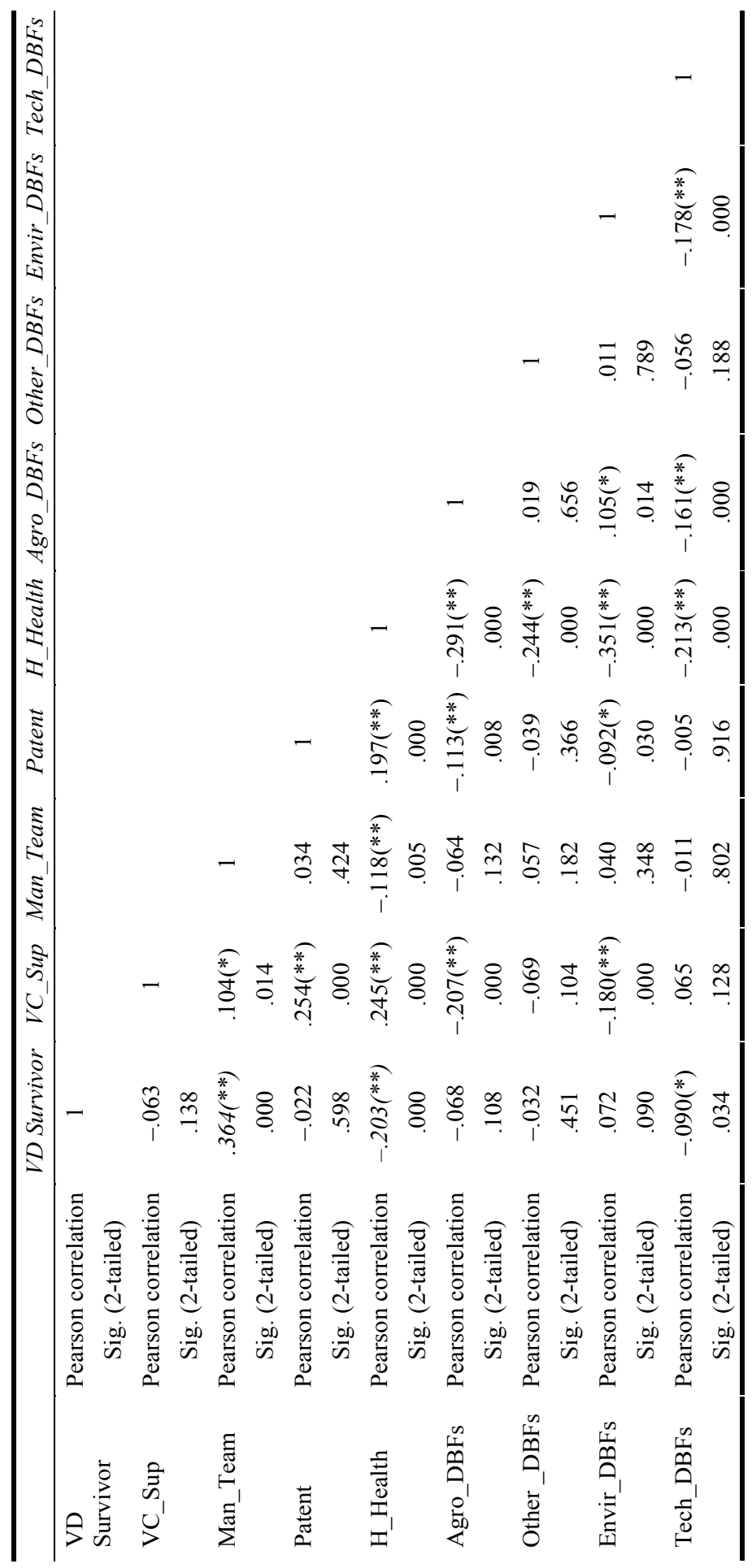


Table 5 Survivor DBFs' logistic regression

\begin{tabular}{|c|c|c|c|c|c|c|}
\hline \multicolumn{7}{|c|}{$\begin{array}{l}\text { Cases in study }=552 . \text { Missing cases }=0 \\
\text { Dependant variable: Survivor DBFs }(Y / N)\end{array}$} \\
\hline \multicolumn{7}{|c|}{ Omnibus tests of model } \\
\hline & \multicolumn{2}{|c|}{ Chi-square } & \multicolumn{2}{|c|}{$D f$} & \multicolumn{2}{|c|}{ Sig. } \\
\hline Step & \multicolumn{2}{|c|}{130.617} & \multicolumn{2}{|c|}{8} & \multicolumn{2}{|c|}{.000} \\
\hline Block & \multicolumn{2}{|c|}{130.617} & \multicolumn{2}{|c|}{8} & \multicolumn{2}{|c|}{.000} \\
\hline Model & \multicolumn{2}{|c|}{130.617} & \multicolumn{2}{|c|}{8} & \multicolumn{2}{|c|}{.000} \\
\hline \multicolumn{7}{|c|}{ Model summary } \\
\hline Step & \multicolumn{2}{|c|}{-2 Log likehood } & \multicolumn{2}{|c|}{$\begin{array}{c}\text { Cox and Snell } \\
R \text {-square }\end{array}$} & \multicolumn{2}{|c|}{$\begin{array}{l}\text { Nagelkerke } \\
R \text {-square }\end{array}$} \\
\hline 1 & \multicolumn{2}{|c|}{616.769} & \multicolumn{2}{|c|}{.211} & \multicolumn{2}{|c|}{.284} \\
\hline \multicolumn{7}{|c|}{ Classification table } \\
\hline \multirow[t]{2}{*}{ Observed } & & & \multicolumn{2}{|c|}{$\begin{array}{c}\text { Predicted } \\
\text { VD_survivors BFs }\end{array}$} & \multicolumn{2}{|c|}{ Percentage correct } \\
\hline & & & 1 & 2 & & \\
\hline \multirow[t]{2}{*}{ Step 1} & VD- & Yes & 225 & 98 & \multicolumn{2}{|c|}{69.7} \\
\hline & $\begin{array}{c}\text { Survivor } \\
\text { DBFs }\end{array}$ & No & 72 & 156 & \multicolumn{2}{|c|}{68.4} \\
\hline \multicolumn{5}{|l|}{ Overall percentage } & \multicolumn{2}{|c|}{69.1} \\
\hline \multicolumn{7}{|c|}{ Variable in the equation } \\
\hline & $B$ & S.E. & Wald & $D f$ & Sig. & $\operatorname{Exp}(b)$ \\
\hline VC_sup & -.388 & .215 & 3.267 & 1 & .071 & .678 \\
\hline Man_Team & 1.610 & .208 & 59.985 & 1 & .000 & 5.005 \\
\hline H_health & -1.583 & .277 & 32.770 & 1 & .000 & .205 \\
\hline Patent & .051 & .211 & .059 & 1 & .809 & 1.052 \\
\hline Agro_DBFs & -1.236 & .314 & 15.538 & 1 & .000 & .290 \\
\hline Other_DBFs & -1.140 & .364 & 9.827 & 1 & .002 & .320 \\
\hline Envir_DBFs & -.476 & .309 & 2.377 & 1 & .123 & .621 \\
\hline Tech_DBFs & -1.290 & .290 & 19.761 & 1 & .000 & .275 \\
\hline Constant & 7.443 & 1.815 & 16.861 & 1 & .000 & $1,708.360$ \\
\hline
\end{tabular}

Given the particularities and non-significance of some results obtained, it seems appropriate to divide our sample according to the motives of exit: bankruptcies versus M\&A. Perhaps our results have been influenced by the heterogeneity of the observations. In this case, DeTienne (2010) warns us that the assimilation of all cases of disappearances and exits of firms in bankruptcy and economic failures can lead us to erroneous or biased conclusions. The factors behind the failure of start-ups may differ completely from those behind M\&A transactions (Wennberg et al., 2010). So to move forward in the analysis of the disappearance of Canadian biotechnology firms, we conceived two new dependent variables; namely, M\&A and bankruptcy. Those new variables will be tested against the same independent variables as introduced in Table 1. 


\subsection{The case of bankrupted DBFs}

In general terms the statistical tests (see Tables 6 and 7) show that bankruptcy of DBFs is explained by the absence of a qualified management team (Man_Team). In fact, our tests show a significant statistical relationship between the presence of a management team and disappearance of this type of firms. We need to clarify that this is a negative correlation $(r=-.304, p=.000)$; meaning that firms without qualified executives have a greater chance of failure and bankruptcy.

Based on the reviewed literature, the presence of a qualified management team constitutes a cornerstone in the life cycle development of a high technology firm. This assumption is confirmed in our study because almost $77 \%$ of the bankrupted firms do not involve qualified executives. This may be explained by the high costs involved in recruiting those qualified human resources, which exceed the financial resources of Canadian biotechnology firms. In addition, the Canadian labour market not only is not large enough to provide all the needs of Canadian biotechnology (Conference Board of Canada, 2005), but also is too fragmented when taking into account the small businesses (Statistics Canada, 2007). It is also important to note that part of the explanation comes from the presence of other actors (e.g., big pharmaceutical firms and venture capital firms) that seem more attractive to those qualified human resources, and thus create a shortage for the small biotechnology firms.

DBFs Bankruptcies and failures are explained also by the absence of venture capital support (VC_sup). The results of our tests show a negative correlation between the failure of young DBFs and the seeking of venture capital services $(r=-.313, p=$ $.000)$. So firms that do not have access to venture capital support are more likely to go bankrupt. This last finding confirms the fact that venture capital firms are indispensable business partners in the case of DBFs. As we have pointed out previously, these kinds of financial Institutions fulfil the needs of the young DBFs in terms of professional coaching, appropriate financial funding, and developing a degree of tolerance to uncertainty. Here, we highlight that almost half of the surveyed DBFs could not access venture capital support. Such a situation may be explained by the great number of small firms (high density) that characterise this Canadian sector. In fact, the large number of small firms leads to a situation where their opportunities to succeed in the screening process used by the venture capital firms is minimised. Therefore, it seems natural when venture capital managers reject a large proportion of biotechnology firms' applications. They think that the development processes are too long, the regulations are not favourable and/or the possibilities for commercialisation are limited (DiMasi et al., 2003; Baeyens et al., 2006). It is relevant to note also that bankrupted DBFs are distinguished by the absence of a qualified management team, and a lack of an intellectual property strategy enabling them to be viewed as a worthy investment by the potential venture capital firms.

Finally, the statistical tests show that the field of specialisation can explain for DBFs' Bankruptcies. More precisely, find a positive correlation $(r=.175, p=.000)$ showing that the biotechnology firms dedicated to agriculture (Agri_DBFs) are more likely to fail. . Based on Table 6, these kinds of DBFs have difficulties recruiting a qualified management team and obtaining venture capital support. 
Table 6 Closed DBFs' correlations

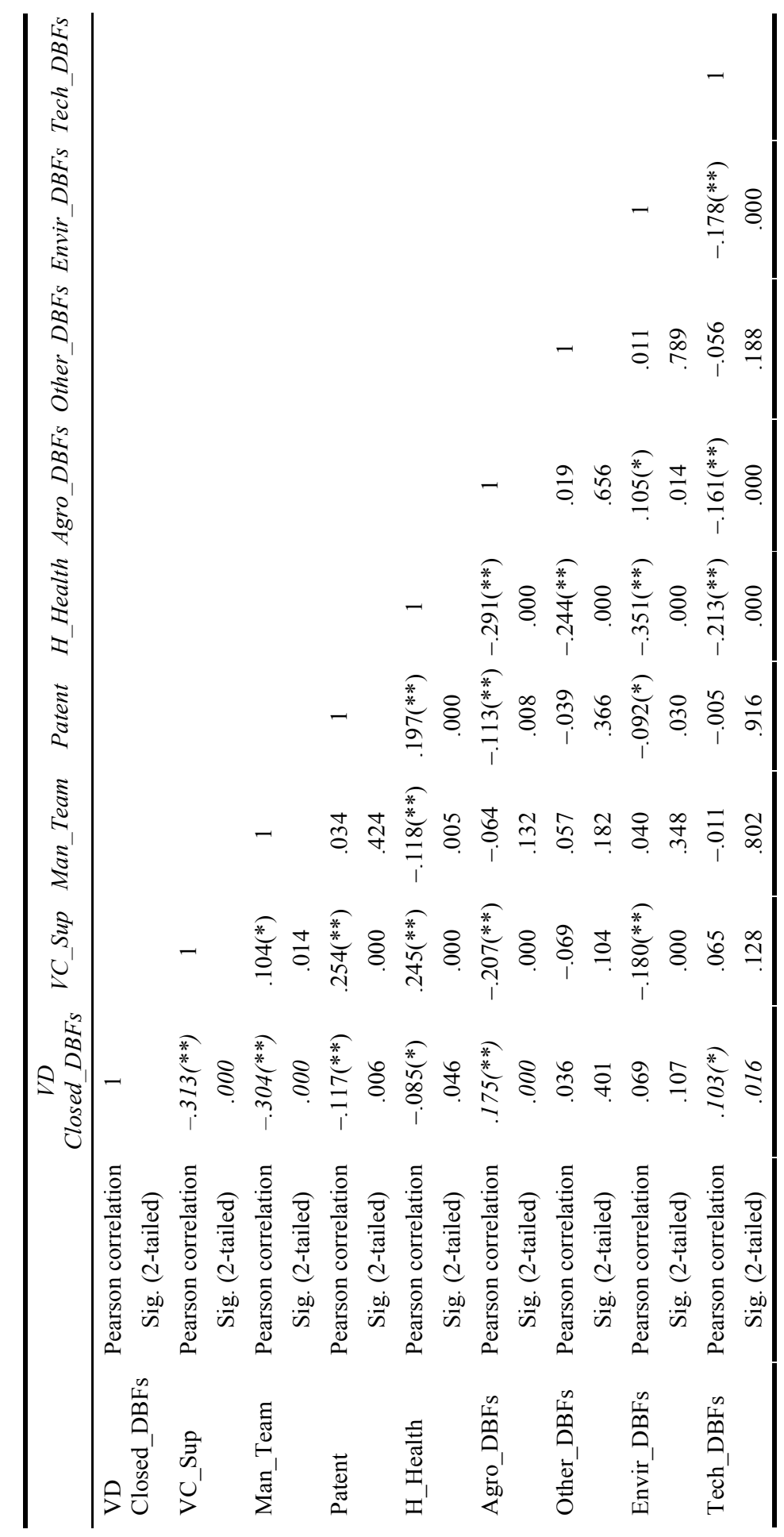


Table 7 Closed DBFs' logistic regression

\begin{tabular}{|c|c|c|c|c|c|c|}
\hline \multicolumn{7}{|c|}{ Cases in study $=552$. Missing cases $=0$} \\
\hline \multicolumn{7}{|c|}{ Dependant variable: Closed DBFs $(\mathrm{Y} / \mathrm{N})$} \\
\hline \multicolumn{7}{|c|}{ Omnibus tests of model } \\
\hline & \multicolumn{2}{|c|}{ Chi-square } & \multicolumn{2}{|c|}{$D f$} & \multicolumn{2}{|c|}{ Sig. } \\
\hline Step & \multicolumn{2}{|c|}{127.821} & \multicolumn{2}{|c|}{8} & \multicolumn{2}{|c|}{.000} \\
\hline Block & \multicolumn{2}{|c|}{127.821} & \multicolumn{2}{|c|}{8} & \multicolumn{2}{|c|}{.000} \\
\hline Model & \multicolumn{2}{|c|}{127.821} & \multicolumn{2}{|c|}{8} & \multicolumn{2}{|c|}{.00} \\
\hline \multicolumn{7}{|c|}{ Model summary } \\
\hline Step & \multicolumn{2}{|c|}{-2 Log likehood } & \multicolumn{2}{|c|}{$\begin{array}{c}\text { Cox and Snell } \\
R \text {-square }\end{array}$} & \multicolumn{2}{|c|}{$\begin{array}{l}\text { Nagelkerke } \\
\text { R-square }\end{array}$} \\
\hline 1 & \multicolumn{2}{|c|}{328.710} & \multicolumn{2}{|c|}{.207} & \multicolumn{2}{|c|}{.368} \\
\hline \multicolumn{7}{|c|}{ Classification table } \\
\hline \multirow[t]{2}{*}{ Observed } & & & \multicolumn{2}{|c|}{$\begin{array}{c}\text { Predicted } \\
V D \_ \text {closed DBFs }\end{array}$} & \multirow{2}{*}{\multicolumn{2}{|c|}{ Percentage correct }} \\
\hline & & & 1 & 2 & & \\
\hline \multirow[t]{2}{*}{ Step 1} & VD- & Yes & 25 & 55 & \multicolumn{2}{|c|}{31.3} \\
\hline & $\begin{array}{l}\text { Closed } \\
\text { DBFs }\end{array}$ & No & 13 & 458 & \multicolumn{2}{|c|}{97.2} \\
\hline \multicolumn{5}{|l|}{ Overall percentage } & \multicolumn{2}{|c|}{87.7} \\
\hline \multicolumn{7}{|c|}{ Variable in the equation } \\
\hline & $B$ & S.E. & Wald & $D f$ & Sig. & $\operatorname{Exp}(b)$ \\
\hline VC_sup & -2.007 & .368 & 29.832 & 1 & .000 & .134 \\
\hline Man_Team & -2.307 & .419 & 30.302 & 1 & .000 & .100 \\
\hline H_health & .366 & .342 & 1.141 & 1 & .285 & 1.442 \\
\hline Patent & -.248 & 328 & .573 & 1 & .449 & .780 \\
\hline Agro_DBFs & .986 & .351 & 7.884 & 1 & .005 & 2.681 \\
\hline Other_DBFs & .313 & .477 & .432 & 1 & .511 & 1.368 \\
\hline Envir_DBFs & .525 & .381 & 1.901 & 1 & .168 & 1.690 \\
\hline Tech_DBFs & 1.210 & .358 & 11.430 & 1 & .001 & 3.352 \\
\hline Constant & 3.577 & 2.244 & 2.541 & 1 & .111 & 35.752 \\
\hline
\end{tabular}

\subsection{The case of $D B F$ s in $M \& A$}

The different statistical tests applied to our sample (see Tables 8 and 9) reveal that M\&A characterising Canadian DBFs can be explained first of all by the presence of venture capital support (VC_sup). Our statistic results show a significant link between exits under M\&A, and the presence of venture capital support. As Table 8 shows, there is a positive correlation $(r=.317, p=.000)$. So, between 1996 and 2010, DBFs that received venture capital support had a greater chance of being involved in M\&A. Based on these results our fifth hypothesis is confirmed. 
Table 8 M\&A DBFs' correlations

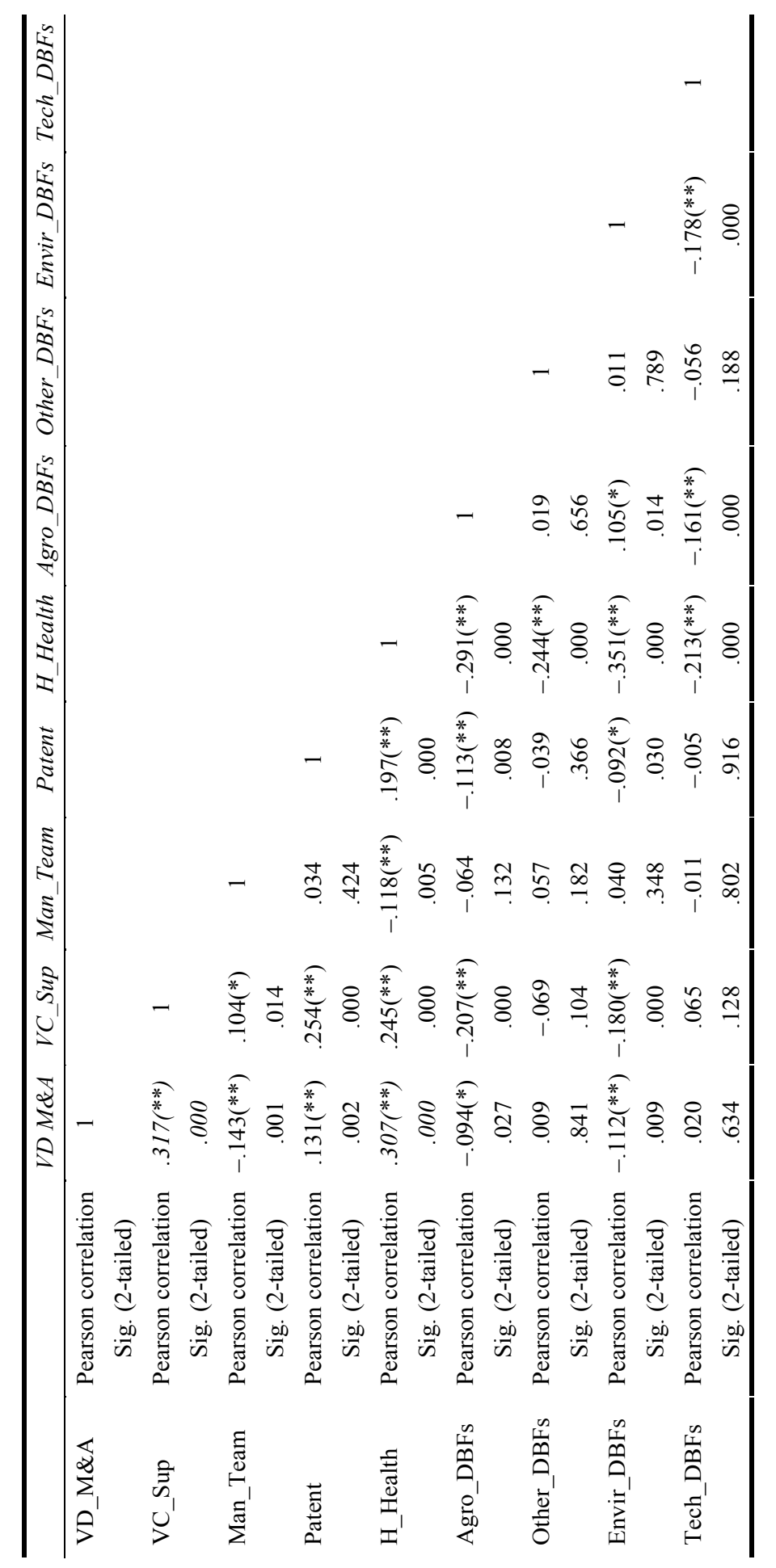


Table 9 M\&A DBFs' logistic regression

\begin{tabular}{|c|c|c|c|c|c|c|}
\hline \multicolumn{7}{|c|}{$\begin{array}{l}\text { Cases in study }=552 . \text { Missing cases }=0 \\
\text { Dependant variable: } M \& A \text { DBFs }(Y / N)\end{array}$} \\
\hline \multicolumn{7}{|c|}{ Omnibus tests of model } \\
\hline & \multicolumn{2}{|c|}{ Chi-square } & \multicolumn{2}{|c|}{$D f$} & \multicolumn{2}{|c|}{ Sig. } \\
\hline Step & \multicolumn{2}{|c|}{122.570} & \multicolumn{2}{|c|}{8} & \multicolumn{2}{|c|}{.000} \\
\hline Block & \multicolumn{2}{|c|}{122.570} & \multicolumn{2}{|c|}{8} & \multicolumn{2}{|c|}{.000} \\
\hline Model & \multicolumn{2}{|c|}{122.570} & \multicolumn{2}{|c|}{8} & \multicolumn{2}{|c|}{.00} \\
\hline \multicolumn{7}{|c|}{ Model summary } \\
\hline Step & \multicolumn{2}{|c|}{-2 Log likehood } & \multicolumn{2}{|c|}{$\begin{array}{c}\text { Cox and Snell } \\
R \text {-square }\end{array}$} & \multicolumn{2}{|c|}{$\begin{array}{l}\text { Nagelkerke } \\
R \text {-square }\end{array}$} \\
\hline 1 & \multicolumn{2}{|c|}{516.631} & \multicolumn{2}{|c|}{.199} & \multicolumn{2}{|c|}{.291} \\
\hline \multicolumn{7}{|c|}{ Classification table } \\
\hline \multirow[t]{2}{*}{ Observed } & & & \multicolumn{2}{|c|}{$\begin{array}{c}\text { Predicted } \\
V D \_M \& A D B F s\end{array}$} & \multirow{2}{*}{\multicolumn{2}{|c|}{ Percentage correct }} \\
\hline & & & 1 & 2 & & \\
\hline \multirow[t]{2}{*}{ Step 1} & VD- & Yes & 80 & 67 & \multicolumn{2}{|c|}{54.4} \\
\hline & $\begin{array}{l}\text { M\&A } \\
\text { DBFs }\end{array}$ & No & 49 & 355 & \multicolumn{2}{|c|}{87.9} \\
\hline \multicolumn{5}{|l|}{ Overall percentage } & \multicolumn{2}{|c|}{78.9} \\
\hline \multicolumn{7}{|c|}{ Variable in the equation } \\
\hline & $B$ & S.E. & Wald & $D f$ & Sig. & $\operatorname{Exp}(b)$ \\
\hline VC_sup & 1.537 & .250 & 37.844 & 1 & .000 & 4.650 \\
\hline Man_Team & -.812 & .229 & 12.554 & 1 & .000 & .444 \\
\hline H_health & 1.874 & .315 & 35.282 & 1 & .000 & 6.514 \\
\hline Patent & .123 & .225 & .300 & 1 & .584 & 1.131 \\
\hline Agro_DBFs & .187 & .368 & .257 & 1 & .612 & 1.205 \\
\hline Other_DBFs & 1.281 & .399 & 10.278 & 1 & .001 & 3.599 \\
\hline Envir_DBFs & .430 & .378 & 1.294 & 1 & .255 & 1.538 \\
\hline Tech_DBFs & .809 & .302 & 7.190 & 1 & .007 & 2.247 \\
\hline Constant & -7.552 & 1.904 & 15.730 & 1 & .000 & .001 \\
\hline
\end{tabular}

M\&A is a part of the development process of new companies dedicated to biotechnology and it is not the consequence of economic failure (Mangematin et al. 2003). By adopting this exit mode, different stakeholders are in a position of strategic reorientation to address shortages of funding sources (Sowlay and Lloyd, 2010). On the one hand, owners of young firms prefer exits through M\&A, also known as industrial exit, to ensure the finalisation and implementation of their research projects (Black and Gilson, 1999; Cumming, 2008). Given the high costs and the managerial complexity needed to develop a new medicine, several scientists who are also co-founders of DBFs claim that M\&A strategies are both a smart as well as indispensable option to maximise the chances of success for firms' innovations. In such case, leaving the scene is a realistic choice that 
allows scientists to be at least part of a big pharma or to join other partners in order to carry on their R\&D activities to the final stages. This strategic orientation offers more reassuring possibilities than the choice of going alone (Graebner and Eisenhardt, 2004). On the other hand, managers of venture capital institutions opt for M\&A transactions in order to earn a return on investment that is more important than an IPO during economic crisis (Sowlay and Lloyd, 2010). Precisely regarding this last point, Ernest and Young (2010) argue that as a result of the last financial crisis (2007-2009), almost half of Canadian biotechnology firms had less than two years of liquidity to survive. This was used to assure the financial resources needed or to find strategies to leave the industry. This can help us to understand why, in our sample, almost $70 \%$ of disappearance was registered in the following two periods: 2002-2004 and 2007-2009. It would be also necessary to underline that the Canadian biotechnology sector is characterised by the presence of many small firms, a situation which diminishes the availability of venture capital (Industry Canada, 2006).

The second factor which can explain M\&A phenomenon characterising Canadian DBFs is the specialisation in human health ( $\mathrm{H}$ _health). Our research reveals that firms dedicated to human health have a greater chance of engaging in M\&A transactions. Based on Table 8, our statistics tests indicate a positive correlation $(r=.307, p=.000)$. In view of the results published by Niosi (2003), our research show that Canadian biotechnology firms dedicated to human health are more likely to be supported by venture capital firms (VC_sup) and to have at least one patent in the USPTO.

Finally our statistical tests indicate that companies dedicated to environment sector (Envir_DBFs) or those run by a qualified management team (Man_Team) are less likely to be involved in strategies for M\&A. As shown in Tables 8 and 9, in both cases we have negative correlations but these statistical tests are not robust enough to lead us to firm conclusions.

\section{Conclusions}

Several works have studied the growth and development of biotechnology firms. However, studies regarding the disappearance of these firms are less numerous. To our knowledge, this paper is among the few studies that examine in depth the different factors characterising the disappearance of young biotechnology firms (e.g., the different disappearance paths as well as their determinants).

Inspired by the results published by Carroll and Hannan (1995), the present study reveals that the disappearance of DBFs is not solely due to bankruptcy and failure. The analysis carried out on the sample, composed of 552 firms, shows that M\&A is the main exit path. Those kinds of disappearances are adopted by young DBFs leaders as a strategic choice to manage the resource limits and/or to deal with economic downturn and financial crisis (Carayannopoulos and Auster, 2010; Danzon et al., 2006). This may be a kind of strategic choice prescribed by venture capital managers and carried out by biotechnology firms' executives (Sowlay and Lloyd, 2010). In other words, we think that exits under M\&A transactions express a sort of business model approved by the different stake holders with the aim of adapting to the constraints of the Canadian biotechnology sector (e.g., strict regulations, limited and fragmented funding sources, insufficient human resources, and an insufficient consumption market). We might even surmise hypothesise that M\&A reflect a sort of competitive advantage in Canadian biotechnology 
(Porter, 1990). One last perspective that could explain this situation would be to consider disappearance under M\&A as a sort of consolidation of the Canadian biotechnology sector, which is dominated by small firms (McKelvey, 2008; Lazonick and Tulum, 2011). At this level we can add also that DBFs represent an important link in the value chain in the pharmaceutical industry. Carayannopoulos and Auster (2010) specify that big pharmaceutical companies do not have organisational flexibility to internalise all the R\&D activities carried out by biotechnology firms. So pharmaceutical executives prefer to acquire promising firms, rather than starting projects based on a product that is already patented by a biotechnology firm.

The present study outlines also the main factors that can explain bankruptcy and failure in the case of DBFs. On one hand, having a qualified management team is a crucial factor to ensure a long life expectancy for DBFs. In addition to professional skills, qualified executives can facilitate access to different business partners. So, our study confirms the postulates advocated by many proponents of RBV theory. On the other hand, the support of venture capital is the other crucial factor to assure long life expectancy. At this level we would like to make reference to the study published in the USA by Puri and Zarutskie (2008) which compares SMEs which have obtained venture capital support with those which have used other sources of funding. Puri and Zarutskie (2008) reveal that SMEs equipped with venture capital support show a higher survival rate during the first four years and they are more likely to integrate stock exchange or attract M\&A transactions.

Beyond financial support, venture capital companies provide appropriate coaching in terms of business management and access to networks of strategic partners. This last point leads us to raise other factors, not addressed in this work, which can be crucial to survival or disappearance of DBFs. Performance depends mainly on the internal capacities and R\&D activities of young DBFs in the development of an innovative product that meets the needs of the market (Hall and Bagchi-Sen, 2002). In addition, leaders of these companies must strengthen their internal capacity through partnership relations with universities and pharmaceutical companies (Hall and Bagchi-Sen, 2007). Moreover, young firms with successful external collaborations 'exploration and exploitation', are those that rely primarily on their own absorptive capacity (Niosi, 2003; Levitte and Bagchi-Sen, 2010).

Whether in the form of bankruptcy or M\&A, DBFs disappearance can also be explained by the limitations imposed by the Canadian institutional environment. For instance, we could mention that the Canadian biotechnology firms are founded prematurely mainly because the universities, where the majority of scientific discoveries occur in Canada, are evaluated according to the number of spin-offs they create (Industry Canada, 2006). Government funding is the main financial source for Canadian biotechnology (OECD, 2009), and most of these government funds are destined for fundamental or basic scientific research (Industry Canada, 2006). It is clear that a strategic change in public policies should be taken on a variety of fronts. As a case in point, Lerner (2010) reports that policy makers must be more prudent when they adapt different strategies to support entrepreneurial and R\&D activities. To limit the premature founding of DBFs, for example, they can rethink the selection criteria by adopting meritocratic systems for granting public funds.

This research opens up the debate for future studies about the disappearance of DBFs. This phenomenon can be examined by focusing mainly on the case of enterprises 
dedicated to human health sector and/or by testing the impact of additional variables such as strategic alliances and geographic externalities in large urban areas. In addition, further comparative studies among OECD members are encouraged in order to shed more light on disappearance of DBFs.

\section{References}

Anyadike-Danes, M., Bonner, K., Hart, M. and Mason, C. (2009) Measuring Business Growth High-growth Firms and Their Contribution to Employment in the UK, NESTA Research, London.

Audretsch, D.B. (2002) 'The innovative advantage of US cities', European Planning Studies, Vol. 10, No. 2, pp.165-176.

Baeyens, K., Vanacker, T. and Manigart, S. (2006) 'Venture capitalists' selection process: the case of biotechnology proposals', International Journal of Technology Management, Vol. 34, No. 12 , pp. $28-46$.

Baldwin, J.R. and Gellatly, G. (2006) Innovation Capabilities: The Knowledge Capital Behind the Survival and Growth of Firms, Statistics Canada, Ottawa, Catalogue No. 11-622-MIE, No. 013.

Baldwin, J-R., Bian, L., Dupuy, R. and Gellatly, G. (2000) Failure Rates for New Canadian Firms: New Perspectives on Entry and Exit, Statistique Canada, Ottawa, Catalogue No. 61-526-XIE.

Baum, J.A.C. and Silverman, B.C. (2004) 'Picking winners or building them? Alliance, intellectual, and human capital as selection criteria in venture financing and performance of biotechnology', Journal of Business Venturing, Vol. 19, No. 3, pp.411-436.

Black, B. and Gilson, R. (1998) 'Venture capital and the structure of capital markets: bank versus capital markets', Journal of Financial Economics, Vol. 47, No. 3, pp.243-277.

Canadian Life Science (2011) 'Canadian life sciences industry forecast 2011' [online] http://www.pwc.com/en_CA/ca/pharma-life-sciences/publications/canadian-life-sciencesindustry-forecast-2011-01-21-en.pdf (accessed 30 June 2011).

Carayannopoulos, S. and Auster, E.R. (2010) 'External knowledge sourcing in biotechnology through acquisition versus alliance: a KBV approach', Research Policy, Vol. 39, No. 2, pp.254-267.

Carroll, G.R. and Hannan, M.T. (1995) Organizations in Industry: Strategy, Structure and Selection, Oxford University Press, New York.

Cefis, E. and Marsili, O. (2011) 'Born to flip. Exit decisions of entrepreneurial firms in high-tech and low tech industries', Journal of Evolutionary Economics, Vol. 21, No. 21, pp.473-498.

Conference Board of Canada (2005) Biotechnology in Canada: A Technology Platform for Growth, Ottawa.

Cooke, P., Heidenreich, M. and Braczy, H-J. (2004) Regional Innovation Systems: The Role of Governances in a Globalized World, Routledge, London.

Cumming, D. (2008) 'Contracts and exits in venture capital finance', The Review of Financial Studies, Vol. 21, No. 5, pp.1947-1982.

Danzon, P., Epstein, A. and Nicholson, S. (2006) 'Mergers and acquisitions in the pharmaceutical and biotech industries', Managerial and Decision Economics, Vol. 28, Nos. 4-5, pp.307-28.

DeTienne, D.R. (2010) 'Entrepreneurial exit as a critical component of the entrepreneurial process: theoretical development', Journal of Business Venturing, Vol. 25, No. 2, pp.203-215.

DiMasi, J-A., Hansen, W.R. and Grabowski, G.H. (2003) 'The price of innovation: new estimates of drug development costs', Journal of Health Economics, Vol. 22, No. 2, pp.151-185.

Einsenhardt, K. and Martin, J.A. (2000) 'Dynamic capabilities: what are they?', Strategic Management Journal, Vol. 21, No. 10, pp.1105-1121. 
Ernst and Young (2010) Beyond Borders: Global Biotechnology Report 2010 [online] http://www.ey.com/Publication/vwLUAssets/Beyond-borders-2010-EN/\$FILE/Beyondborders-2010-EN (accessed 11 April 2011).

Ernst and Young (2012) Beyond Borders Global Biotechnology Report 2012 [online] http://www.ey.com/Publication/vwLUAssets/Beyond_borders_2012/\$FILE/Beyond_borders_ 2012 (accessed 30 February 2013).

Gompers, P. and Lerner, J. (2001) 'The venture capital revolution', Journal of Economic Perspective, Vol. 15, No. 2, pp.145-168.

Graebner, M.E. and Eisenhardt, K.M. (2004) 'The seller's side of the story: acquisition as courtship and governance as syndicate in entrepreneurial firms', Administrative Science Quarterly, Vol.49, No. 3, pp.366-403.

Granovetter, M. (1973) 'The strength of weak ties', American Journal of Sociology, Vol. 78, No. 6, pp.1360-1380.

Haeussler, C. (2007) 'Proactive versus reactive M\&A activities in the biotechnology industry', Journal of High Technology Management Research, Vol. 17, No. 2, pp.109-123.

Hall, B. and Lerner, J. (2010) 'The financing of R\&D and innovation', in Hall, B. and Rosenberg, N. (Eds.): Handbook of the Economics of Innovation, Elsevier-North Holland.

Hall, L.A. and Bagchi-Sen, S. (2001) 'An analysis of R\&D, innovation and business performance in the US biotechnology industry', International Journal of Biotechnology, Vol. 3, Nos. 3-4, pp.267-286.

Hall, L.A. and Bagchi-Sen, S. (2002) 'A study of R\&D, innovation, and business performance in the Canadian biotechnology industry', Technovation, Vol. 22, No. 4, pp.231-244.

Hall, L.A. and Bagchi-Sen, S. (2007) 'An analysis of firm-level innovation strategies in the US biotechnology industry', Technovation, Vol. 27, Nos. 1-2, pp.4-14.

Hannan, M.T. and Freeman, J. (1977) 'The population ecology of organizations', American Journal of Sociology, Vol. 82, No. 5, pp.929-964.

Hochberg, Y.A., Ljungqvist, A. and Lu, Y. (2007) 'Whom you know matters: venture capital networks and investment performance', Journal of Finance, Vol. 62, No. 1, pp.251-301.

Industry Canada (2006) The Canadian Biopharmaceutical Industry Technology Roadmap: Technologies to Improve $R \& D$ Productivity, Industry Canada, Ottawa, Catalogue No. Iu44-31/2006-MRC.

Jovanovic, B. (1982) 'Selection and the evolution of industry', Econometrica, Vol. 50, No. 3, pp.649-670.

Kenney, M. (1986) Biotechnology: The University-Industrial Complex, Yale University Press, New Haven.

Kenney, M. (2011) 'How venture capital became a component of the US national system of innovation', Industrial and Corporate Change, Vol. 20, No. 6, pp.1677-1724.

Lazonick, W. and Tulum, O. (2011) 'US biopharmaceutical finance and the sustainability of the biotech business model', Research Policy, Vol. 40, No. 9, pp.1170-1187.

Lerner, J. (2010) Boulevard of Broken Dreams: Why Public Efforts to Boost Entrepreneurship and Venture Capital Have Failed - and What to Do About it, Princeton University Press, New Jersey.

Lester, R.H., Certo, S.T., Dalton, C.M., Dalton, D.R. and Cannella, A.A. (2006) 'Initial offering investor valuations: a examination of top management team and environmental uncertainty', Journal of Small Business Management, Vol. 44, No. 1, pp.1-26.

Levittea, M.Y. and Bagchi-Sen, S. (2010) 'Demographics, innovative outputs and alliance strategies of Canadian biotech firms', European Planning Studies, Vol. 18, No. 5, pp.669-690.

Mangematin, V., Lemarié, S., Boissin, J-P., Catherine, D., Corolleur, F., Coronini, R. and Trommette, M. (2003) 'Development of SMEs and heterogeneity of trajectories: the case of biotechnology in France', Research Policy, Vol. 32, No. 4, pp.621-638.

Mata, J. (1994) 'Firm growth during infancy', Small Business Economics, Vol. 6, No. 1, pp.27-39. 
McKelvey, M. (2008) Emerging Business Models and Institutional Drivers Bioeconomy 2030, OECD, Paris [online] http://www.oecd.org/futures/bioeconomy/2030 (accessed January 2011).

Niosi, J. (2003) 'Alliances are not enough explaining rapid growth in biotechnology firms', Research Policy, Vol. 32, No. 5, pp.737-750.

Niosi, J. (2011) 'Complexity and path dependence in biotechnology innovation systems', Industrial and Corporate Change, Vol. 20, No. 6, pp.1795-1826.

Niosi, J. and Banik, M. (2005) 'The evolution and performance of biotechnology regional systems of innovation', Cambridge Journal of Economics, Vol. 29, No. 3, pp.343-357.

Niosi, J. and Queenton, J. (2010): 'Knowledge capital in biotechnology industry: impacts on Canadian firm performance', International Journal of Knowledge-Based Development, Vol. 1, Nos. 1-2, pp.136-151.

OECD (2005) A Framework for Biotechnology Statistics, OECD, Paris [online] http://www.oecd.org/dataoecd/5/48/34935605.pdf (accessed 10 June 2009).

OECD (2009) OECD Biotechnology Statistics 2009, OECD, Paris [online] http://www.oecd.org/dataoecd/4/23/42833898.pdf (accessed 5 April 2011).

Patzelt, H., Schweizer, L. and zu Knyphausen-Aufseß, D. (2007) 'Mergers and acquisitions of German biotechnology startups', International Journal of Biotechnology, Vol. 9, No. 1, pp.1-22.

Penrose, E. (1959) The Theory of the Growth of the Firm, Oxford University Press, New York. .

Pisano, G. (2006) 'Can science be a business? Lessons from biotech', Harvard Business Review, Vol. 84, No. 10, pp.114-125.

Porter, M. (1990) The Competitive Advantage of Nations, Free Press, New York.

Powell, W.W., Koput, K.W., Bowie, J.F. and Smith-Doerr, L. (2002) 'The spatial clustering of science and capital: Accounting for biotech firm-venture capital relationships', Regional Studies, Vol. 36, No. 3, pp.291-305.

Puri, M. and Zarutskie, R. (2008) On the Lifecycle Dynamics of Venture-Capital-and Non-Venture-Capital-Financed Firms, Working Papers 08-13, Center for Economic Studies, US Census Bureau.

Rhyne L.C. (2009) 'Business model design for biotechnology firms', International Journal of Business Innovation and Research, Vol. 3, No. 3, pp.298-310.

Rothaermel, F.T. and Deeds, D. (2006) 'Alliance type, alliance experience and alliance management capability in high-technology ventures', Journal of Business Venturing, Vol. 21, No. 4, pp.429-460.

Song, M., Podoynitsyna, K., Bij, V-H. and Halman, I-M. (2008) 'Success factors in new ventures: a meta-analysis', Journal of Product Innovation Management, Vol. 25, No. 1, pp.7-27.

Sowlay, M. and Lloyd, S. (2010) 'The current M\&A environment and its strategic implications for emerging biotherapeutics companies', Journal of Commercial Biotechnology, Vol. 16, pp.109-119.

Statistics Canada (2007) Selected Results of the Biotechnology Use and Development Survey 2005, Ottawa.

Teece, D-J. (2009) Dynamic Capabilities and Strategic Management: Organizing for Innovation and Growth, Oxford University Press, New York.

Van Moorsel, D., Cranfield, J. and Sparling, D. (2007) 'Factors affecting biotechnology innovation in Canada: analysis of the 2001 biotechnology use and development survey', International Journal of Biotechnology, Vol. 9, No. 1, pp.39-59.

Wennberg, K., Wiklund, J., DeTienne, D.R. and Cardon, M.S. (2010) 'Reconceptualizing entrepreneurial exit: divergent exit routes and their drivers', Journal of Business Venturing, Vol. 25, No. 4, pp.361-375. 
Wilbon, A.D. (2002) 'Predicting survival of high-tech initial public offerings', Journal of High Technology Management Research, Vol. 13, No. 1, pp.27-141.

Zucker, L., Darby, M-R. and Brewer, M.B. (1998) 'Intellectual human capital and the birth of US biotechnology enterprises', American Economic Review, Vol. 88, No. 1, pp.290-336.

Zucker, L.G., Darby, M.R. and Armstrong, J.S. (2002) 'Commercializing knowledge: university science, knowledge capture, and firm performance in biotechnology', Management Science, Vol. 48, No. 1, pp.138-153. 